\title{
Arames Tubulares Celulósicos: Influência da Adição de Polímeros sobre a Estabilidade do Processo e Propriedades do Metal de Solda Produzido
}

\author{
Cláudio Turani Vaz ${ }^{1}$, Alexandre Queiroz Bracarense², Leonardo Schiavo de Rezende ${ }^{1}$, Pedro Henrique Ribeiro Menezes² \\ 1 Centro Federal de Educação Tecnológica de Minas Gerais - CEFET, Departamento de Engenharia de Materiais, \\ Belo Horizonte, MG, Brasil. \\ 2 Universidade Federal de Minas Gerais - UFMG, Departamento de Engenharia Mecânica, Belo Horizonte, MG, Brasil.
}

Recebido: 29 Nov., 2017

Aceito: 24 Jan., 2018

E-mail: claudioturani@gmail.com (CTV)
Resumo: Não há na literatura registros de estudos com o objetivo de desenvolver e avaliar o desempenho de arames tubulares com uma base de formulação celulósica para aplicações em campo sem a necessidade de emprego de gases de proteção. O objetivo deste trabalho foi produzir arames tubulares desta classe com adições de polímero para avaliar sua influência sobre a estabilidade do processo e propriedades do metal de solda. A avaliação dos arames demonstrou a viabilidade de produção dos consumíveis em escala piloto. Os metais de solda depositados pelos arames sem e com 7,5\% de polímero apresentaram composição química comparável aos eletrodos revestidos celulósicos que serviram como fórmula base. Por sua vez, o arame tubular produzido com 15\% de polímero apresentou redução significativa nos teores de C, Si e Mn. O hidrogênio difusível do metal de solda não apresentou alterações significativas para as fórmulas avaliadas. A macrografia dos cordões de solda não indicou presença de poros e as medidas de penetração apontaram um aumento desta em função da quantidade de polímero. A avaliação dos sinais elétricos demonstrou maior estabilidade na soldagem do arame tubular contendo maior quantidade de polímero.

Palavras-chave: Arames tubulares; Celulósico; Polímero; Metal de solda; Transferência metálica.

\section{Cellulosic Flux Cored Wires: The Influence of Polymer Addition on Process Stability and Properties of Weld Metal Produced}

\begin{abstract}
There are no papers describing the development and evaluation of self shielded cellulosic cored wires for field welds applications. The paper objective was to produce this consumable with polymer additions and evaluate its effect on the process stability of weld metal produced by cellulosic flux cored. The evaluation of cored wires showed the feasibility to make them at pilot plant. The chemical composition of weld metal produced by wire without $(0,0 \%)$ or with $7,5 \%$ polymer match the cellulosic covered electrode composition which was the base formula. On the other hand, the $15 \%$ polymer cored wire presented in comparison with to the others consumables, substantial carbon, silicon and manganese content reduction. Evaluating the weld metal diffusible hydrogen content cannot be observed a variation as a function of polymer content. The weld bead macrographic analysis does not indicate porosity and the penetration improved as a consequence of polymer increasing. The electrical signal evaluation showed more arc stability as a result of polymer content increasing.
\end{abstract}

Key-words: Cored wires; Cellulosic; Polymer; Weld metal; Metallic transfer.

\section{Introdução}

A utilização do processo de soldagem com arames tubulares tem se intensificado ao longo das últimas décadas. Este movimento começou se iniciou nas décadas de 60 e 70 nos Estados Unidos da América, 80 no Japão e, mais recentemente, atingiu países como o Brasil. Redução gradativa no preço do consumível, disponibilidade de uma ampla gama de ligas, índices de produtividade comparável ou superior ao obtido na soldagem com arames maciços e características operacionais diferenciadas, são alguns dos aspectos responsáveis por esta expansão [1]. Neste cenário, arames contendo fluxos metálicos e não metálicos dos tipos rutílicos, básicos e autoprotegidos já se encontram consolidados e estão disponíveis comercialmente. Entretanto, o aperfeiçoamento e desenvolvimento de novos tipos ou de variações das existentes contendo características operacionais e metalúrgicas capazes de atender ou otimizar determinadas aplicações, não têm sido observadas. Entre as inúmeras razões para tal fato pode-se citar o maior
Este é um artigo publicado em acesso aberto (Open Access)
sob a licença Creative Commons Attribution Non-Commerci que permite uso, distribuição e reprodução em qualquer meio, sem restriçōes desde que sem fins comerciais e que 0 trabalho original seja corretamente citado. 
Arames Tubulares Celulósicos: Influência da Adição de Polímeros sobre a Estabilidade do Processo e

Propriedades do Metal de Solda Produzido

foco no desenvolvimento de equipamentos de soldagem com novas tecnologias de controle. Em consonância com esta afirmação Surian [2], em uma revisão sobre os recentes desenvolvimentos no campo de consumíveis para soldagem, relata que a evolução ao longo dos últimos 40 anos tem sido mais intensa no campo dos processos. Ainda segundo a autora, os avanços no campo da metalurgia da soldagem observados a partir do trabalho realizado por Glyn Evans, foram fundamentais para a mudança recente desta situação e retomada das pesquisas no campo dos consumíveis.

Como qualquer consumível para soldagem ao arco elétrico, a primeira dificuldade a ser superada no desenvolvimento de arames tubulares envolve o acesso a um equipamento que seja capaz de produzir este com os níveis de qualidade exigidos em escala piloto. Para atender a esta demanda Oliveira [3] projetou e construiu uma máquina para fabricação de arames tubulares em laboratório. Consumíveis com diferentes formulações foram produzidos neste equipamento e tiveram algumas de suas características investigadas [4,5]. No ano de 2014 foi depositado um pedido de patente de arames tubulares com fluxos do tipo celulósico [6]. Um consumível desta classe se apresenta como alternativa competitiva aos demais nas soldagens em campo como, por exemplo, de tubulações. A possibilidade do emprego de um processo semiautomático sem gás de proteção externo em passes de raiz e enchimento de chanfros fora da posição plana ainda também se apresenta como um desafio nos dias de hoje. Entretanto, para viabilizar tal tecnologia é necessário superar desafios tecnológicos que envolvem desde a produção do consumível e características operacionais indesejáveis decorrentes de um fluxo celulósico.

Adicionalmente, não se sabe qual será o comportamento de um arame tubular celulósico durante a soldagem e quais propriedades irá apresentar o metal de solda produzido. Espera-se, contudo, certo grau de similaridade com eletrodos celulósicos. Neste tipo de consumível a elevada quantidade de material combustível orgânico proporciona algumas características singulares: elevado volume de gás de proteção em função da decomposição da celulose, elevada penetração devido ao forte jato de plasma e um metal de solda com elevada propensão a fissuração a frio em decorrência do teor de hidrogênio difusível no metal de solda [7]. Assim, são necessárias adequações na formulação que podem incluir, além do ajuste na quantidade de cada um dos componentes, utilização de novas matérias primas. Trabalhos envolvendo o emprego de polímeros como matéria prima integrante do revestimento de eletrodos destinados à soldagem apresentaram resultados promissores quanto a melhoria durante o processo (transferência metálica e estabilidade) [8] e no metal de solda (microestrutura e propriedades) $[9,10]$. Mesmo se tratando de consumíveis com características distintas, a utilização deste tipo de matéria prima pode ser uma alternativa para minimizar características negativas associadas à celulose.

Este trabalho teve como objetivo produzir arames tubulares celulósicos em escala piloto adicionando diferentes quantidades de polímero para avaliar a capacidade deste de melhorar aspectos operacionais (transferência metálica) e metalúrgicos (hidrogênio difusível do metal de solda). Adicionalmente foram avaliados os arames produzidos na máquina piloto e, de modo exploratório, características do metal de solda produzido como morfologia e composição química.

\section{Materiais e Métodos}

\subsection{Produção dos arames}

Os testes propostos neste trabalho foram realizados com arames tubulares fabricados com três quantidades de distintas de polímero conforme indicado na Tabela 1.

O equipamento utilizado na fabricação dos arames é apresentado na Figura 1. Ele é constituído por dois pares de rolos que realizam a conformação inicial da fita, sistema de dosagem e alimentação de fluxo, dois pares de rolos para fechamento do tubo, fieira e tambor para tracionamento e bobinamento do arame. A sequência proposta inicialmente para conformação da fita é apresentada na Figura 2.

Na produção dos arames deste trabalho o sistema dosador foi ajustado para máximo preenchimento da seção. Adequações realizadas no equipamento eliminaram a necessidade do último par de solos de fechamento conforme havia sido proposto no início dos trabalhos. Depois de produzido, o arame foi passado repetidas vezes pelo conjunto constituído pela caixa com fieira, lubrificante e tambor de tracionamento até ser obtido um diâmetro 
Tabela 1. Formulações utilizadas.

\begin{tabular}{cccc}
\hline Matéria prima & $\mathbf{0 , 0} \%$ Polímero & $\mathbf{7 , 5} \%$ Polímero & $\mathbf{1 5 , 0 \%}$ Polímero \\
Celulose & 20,0 & 20,0 & 20,0 \\
Polímero & 0,0 & 7,5 & 15,0 \\
Pó de ferro & 39,0 & 31,5 & 24,0 \\
Outros compostos & 41,0 & 41,0 & 41,0 \\
\hline
\end{tabular}

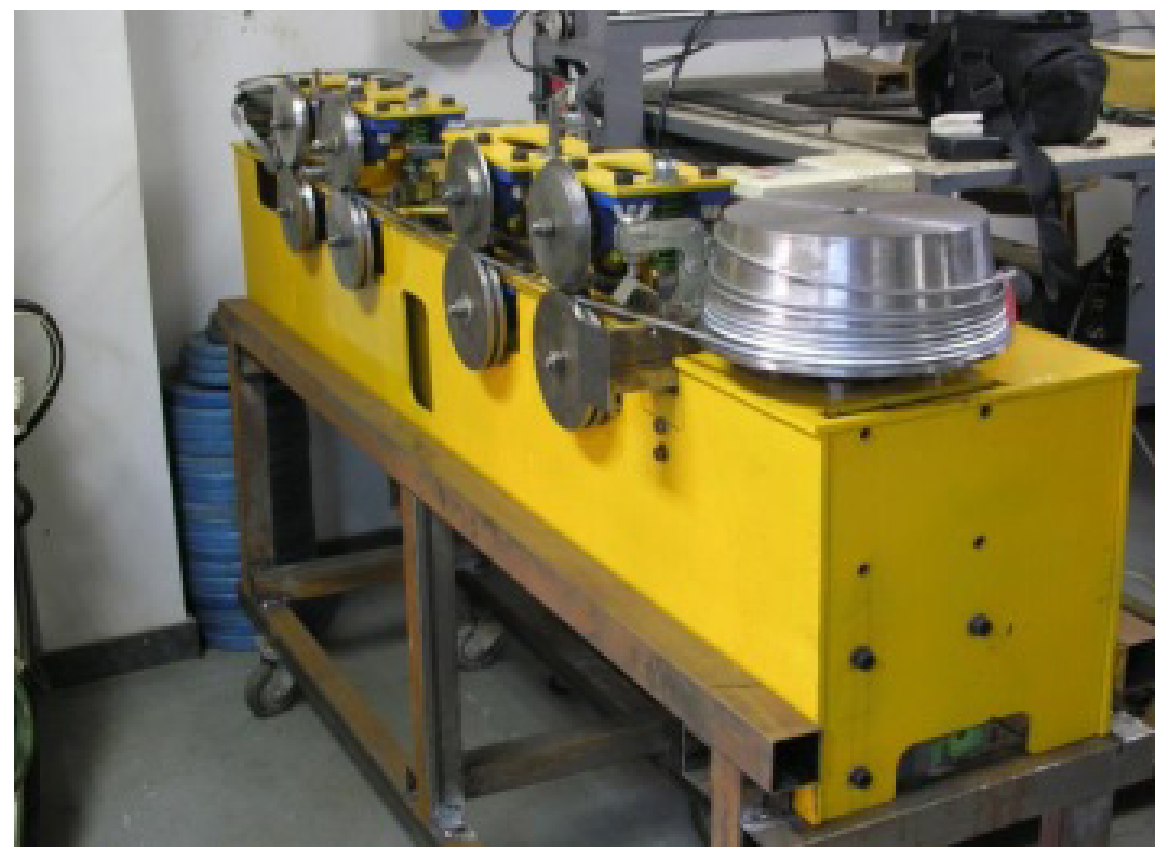

Figura 1. Máquina piloto utilizada na fabricação dos arames [3].

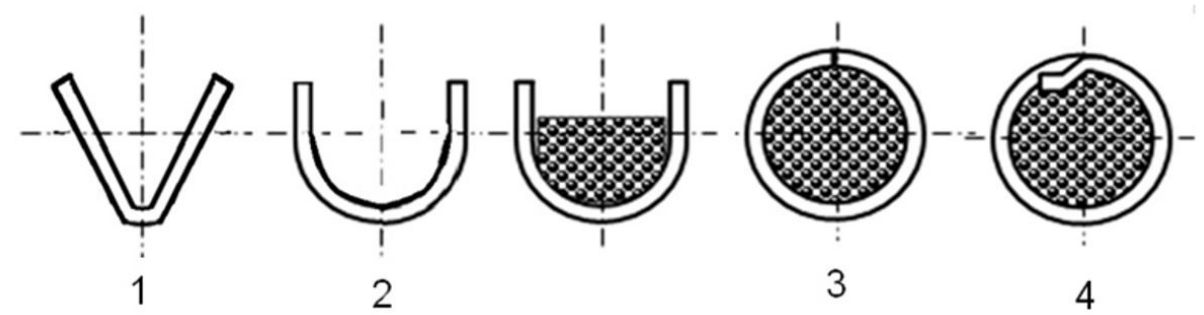

Figura 2. Sequência de conformação do arame [3].

nominal de 2,2 mm. A dimensão final do arame, mesmo não sendo padrão das especificações AWS, foi escolhida com base em critérios técnicos, ou seja, fieiras disponíveis e possibilidade de trefilação sem rompimento do arame.

Com o objetivo de avaliar a consistência dos arames produzidos estes foram submetidos a uma série de ensaios. Inicialmente, com o auxílio de um micrômetro externo com capacidade de 0 a 25 mm e resolução de $0,001 \mathrm{~mm}$ foram realizadas dez medidas de diâmetro em diferentes pontos ao longo de toda a extensão dos arames produzidos. Durante a soldagem foram cortadas seções de arame com o comprimento aproximado de $100 \mathrm{~mm}$ em diferentes regiões do arame. Tais seções foram pesadas em uma balança com faixa de operação de 0,02 a $20 \mathrm{~g}$ 
e resolução de 0,001 g. Após esta pesagem os arames foram abertos e o fluxo interno foi removido. A parte metálica foi novamente pesada de tal modo que fosse possível determinar o percentual de fluxo em cada um dos arames produzidos. Dez amostras de arame com comprimento aproximado de $5 \mathrm{~mm}$ foram cortadas, embutidas, lixadas e levadas a uma lupa estereoscópica para aquisição de macros da seção transversal. As áreas do fluxo e total dos arames foram determinadas com o auxílio do software analisador de imagens ImageJ.

\subsection{Soldagem}

A soldagem dos arames tubulares produzidos foi efetuada empregando um equipamento constituído por fonte inversora AristoMig 5001i com fator de trabalho de 400 A a 100\%, alimentador de arame Aristo Feed 3004 e sistema de controle U8. Os cordões foram depositados de modo mecanizado com o auxílio do dispositivo ilustrado na Figura 3 utilizando os parâmetros listados na Tabela 2.

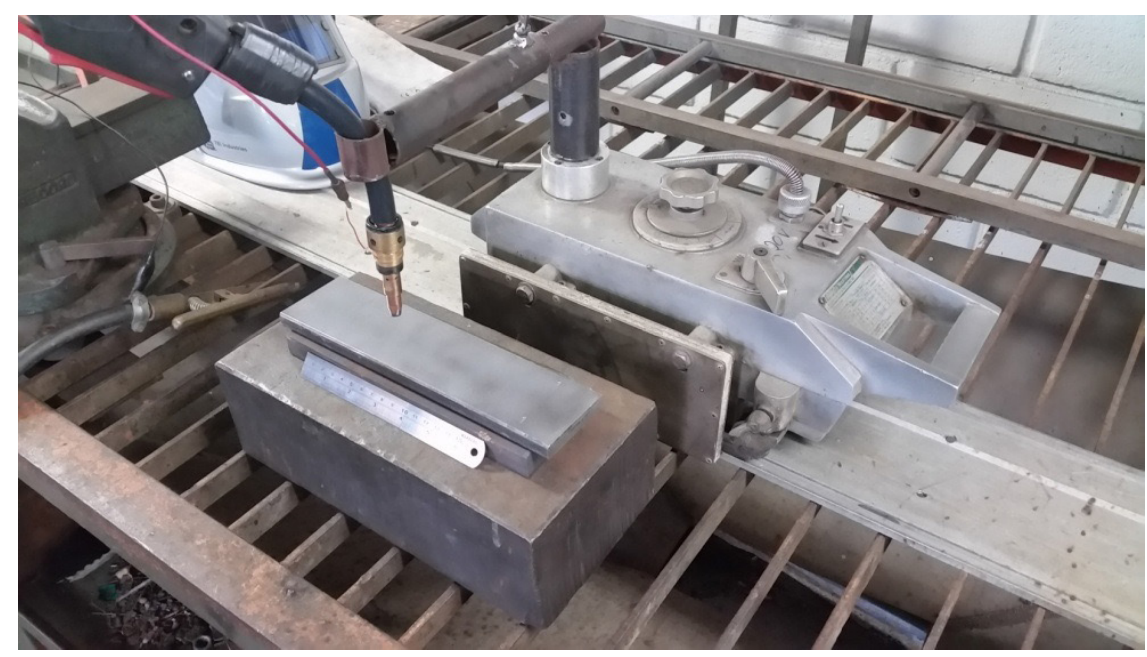

Figura 3. Sistema empregado na mecanização das operações de soldagem.

Tabela 2. Parâmetros de soldagem.

\begin{tabular}{cc}
\hline Intensidade de corrente & $190 \mathrm{~A}$ \\
Tensão & $25 \mathrm{~V}$ \\
Velocidade de soldagem & $22,5 \mathrm{~cm} / \mathrm{min}$ \\
Distância bico de contato peça & $25 \mathrm{~mm}$ \\
Gás de proteção & Não aplicável \\
\hline
\end{tabular}

\subsection{Monitoramento de tensão e corrente de soldagem}

Com o objetivo de coletar os valores de tensão e corrente durante a soldagem foi empregado o sistema de aquisição de dados cujo esquema é ilustrado na Figura 4. Após a coleta a uma taxa de 1000 pontos por segundo os dados foram analisados com o auxílio do programa Sinal para determinação da tensão e corrente médias $\left(V_{m}\right.$ e $\left.I_{m}\right)$, desvios padrão da tensão e corrente médias $\left(\sigma V_{m}\right.$ e $\left.\sigma I_{m}\right)$, tensão média de arco atuando $\left(V_{a m}\right)$ e o desvio padrão da tensão média de arco atuando $\left(\sigma \mathrm{V}_{M}\right)$. Assim, foi possível avaliar alterações na tensão média e corrente média para as diferentes fórmulas de consumível estudadas. Também, com o auxílio do mesmo software, foram gerados histogramas de tensão, cálculos da quantidade de curtos-circuitos rápidos e coeficiente de variação (CV) da tensão de soldagem. 


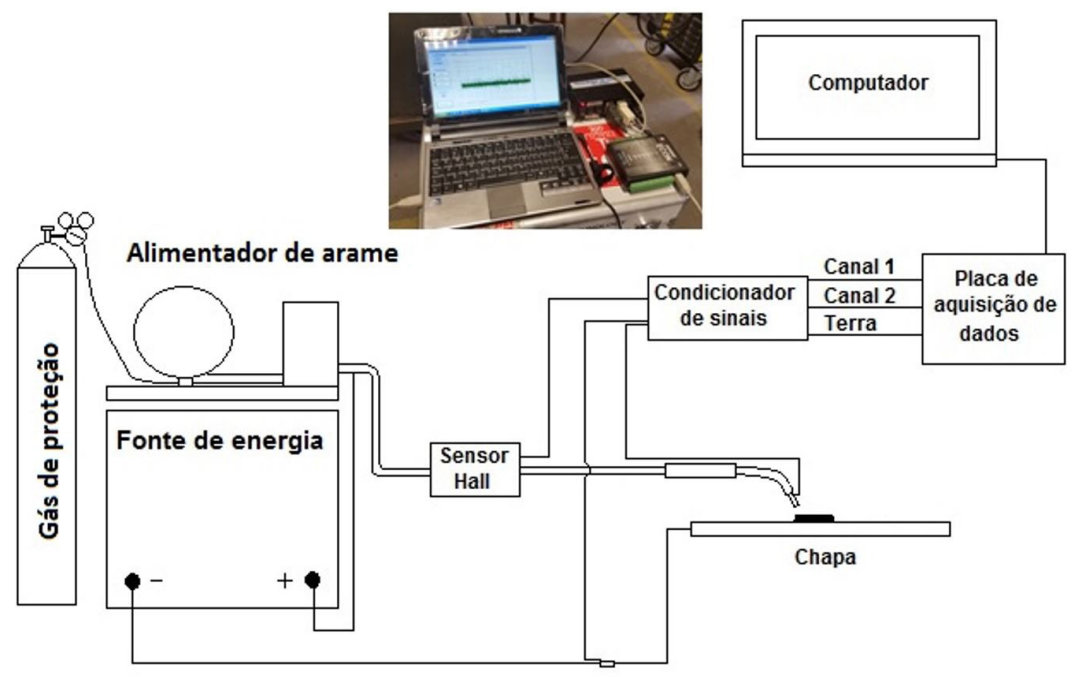

Figura 4. Sistema utilizado na aquisição de dados.

\subsection{Análise do metal de solda}

Na determinação da composição química dos cordões de solda foram depositados cordões sobre uma chapa de aço ASTM A36 com dimensões $12,7 \times 60 \times 50 \mathrm{~mm}$ seguindo os padrões recomendados pela especificação AWS [11] de tal maneira que fosse possível eliminar o efeito da diluição. Cordões que formavam a última camada foram lixados para formar uma superfície plana com área suficiente para análise química via espectrofotometria de emissão ótica. Para avaliar a morfologia amostras foram retiradas em três diferentes regiões de cordões depositados sobre uma chapa de aço ASTM A36 com dimensões de $12,7 \times 60 \times 250 \mathrm{~mm}$ utilizando um dispositivo para soldagem mecanizada. Após a preparação as imagens macrográficas foram coletadas em uma lupa estereoscópica e, com o auxílio do programa Image J, foram realizadas medidas de penetração, largura, reforço e áreas de metal de base e reforço para cálculo da diluição.

O teor de hidrogênio difusível do metal de solda foi determinado de acordo com a especificação AWS A4.3 [12] utilizando cromatografia gasosa. A deposição dos cordões de solda destinados a esta medição foi realizada de modo mecanizado de modo a manter fixos tanto a velocidade de soldagem quanto a distância bico de contato peça conforme ilustrado na Figura 5. Foram realizadas quatro medições para cada um dos arames estudados neste trabalho.

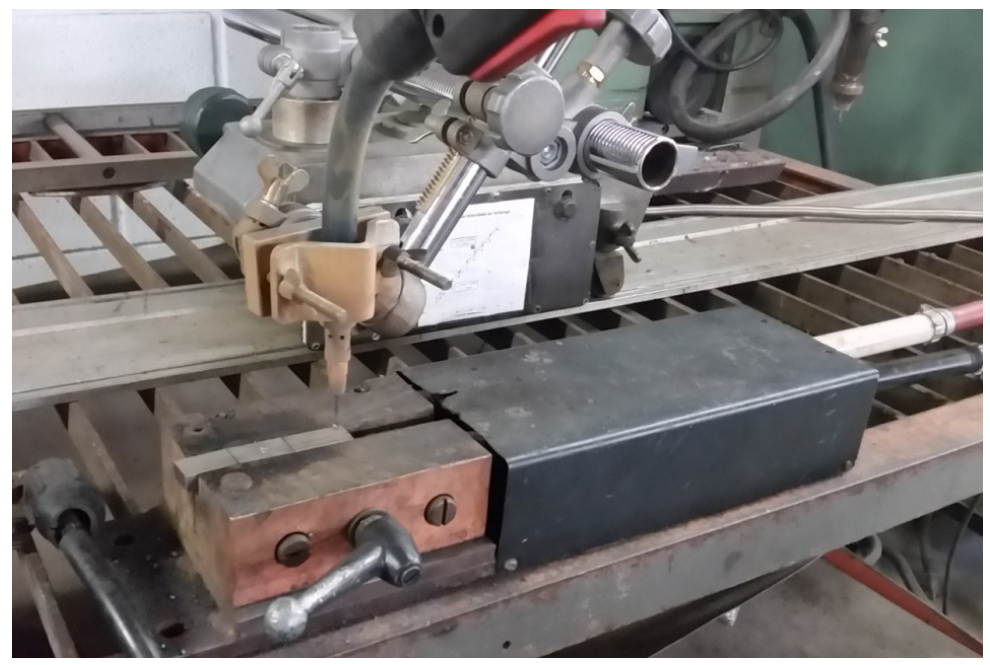

Figura 5. Sistema mecanizado empregado na deposição do metal de solda para medição do teor de hidrogênio difusível. 
Arames Tubulares Celulósicos: Influência da Adição de Polímeros sobre a Estabilidade do Processo e Propriedades do Metal de Solda Produzido

\section{Resultados e Discussão}

\subsection{Avaliação dos arames produzidos}

As medidas de diâmetro realizadas ao longo dos arames tubulares produzidos, os valores médios e intervalos de confiança (95\%) são apresentadas na Figura 6. Nota-se que as medições apresentaram aleatoriedade ao longo da extensão do arame e não ultrapassaram 0,02 $\mathrm{mm}$ em cada arame produzido. As linhas horizontais em negrito representam os valores de 2,12 e 2,28 $\mathrm{mm}$ que seriam, tomando com base os critérios dimensionais estabelecidos
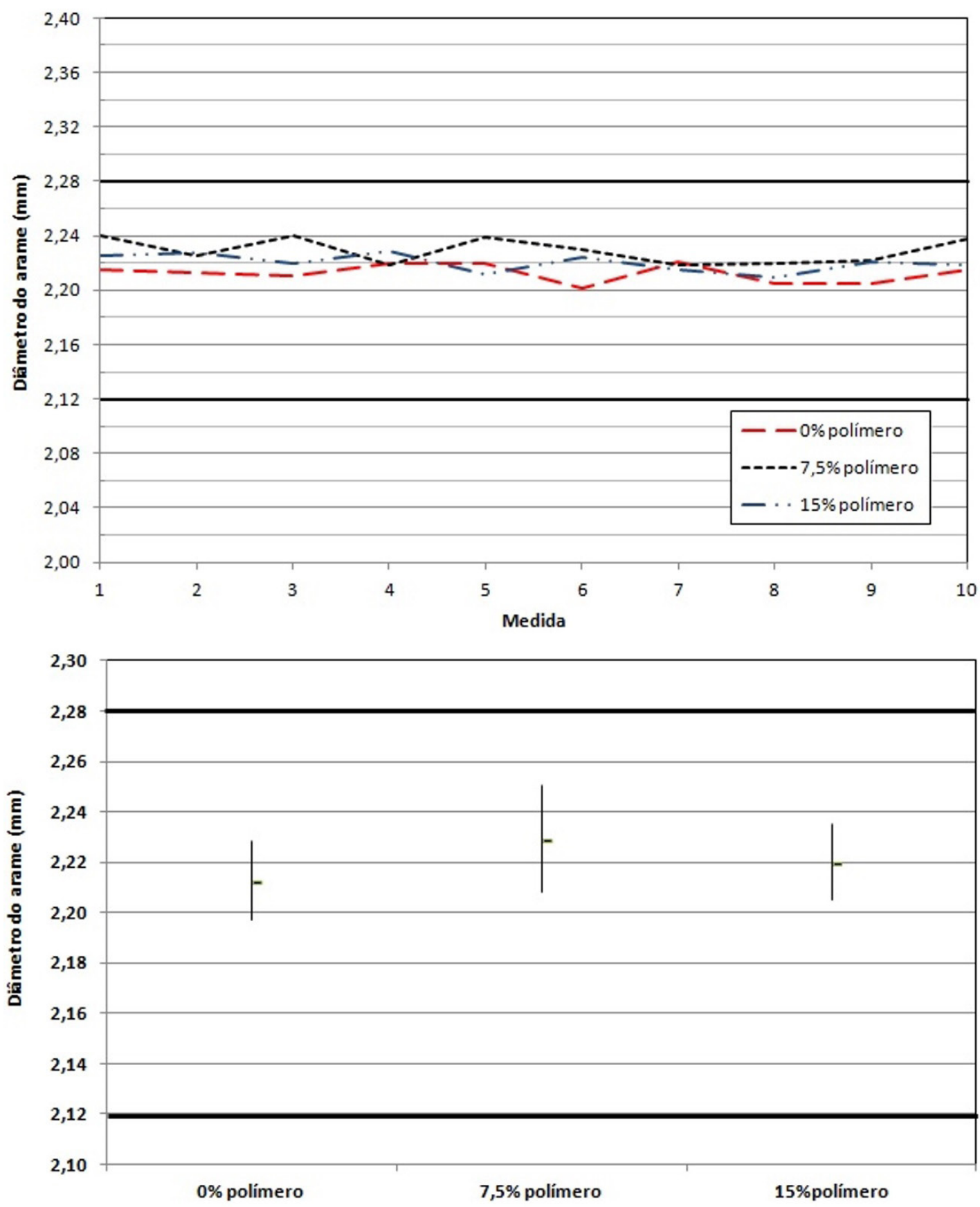

Figura 6. Diâmetro dos arames produzidos - medições individuais ao longo do arame e média (Intervalo de confiança 95\%). 
pela AWS A5.20 [11], os limites inferior e superior de especificação para arames com diâmetro nominal superior a $1,70 \mathrm{~mm}$. A variação nas medidas possivelmente não está associada ao processo de fabricação e pode ser justificada pelas condições do consumível, método de medição e instrumento utilizados. Como os arames foram bobinados após trefilação há presença de deformação plástica (fenômeno conhecido como "cast") que pode influenciar medições realizadas quando se emprega um micrômetro de ponta plana. Ao comparar os valores médios de diâmetro calculados para cada um dos consumíveis deste estudo apresentados no gráfico nota-se, pela significativa sobreposição dos intervalos para o nível de confiança adotado (95\%), que não há diferença entre eles.

Porcentagem de fluxo nos arames tubulares e a área de fluxo calculada a partir das macrografias da seção transversal dos arames se encontram na Figura 7. As medidas de porcentagem realizadas em diferentes regiões de cada um dos arames demonstram, em função da pequena variação, consistência na alimentação e homogeneização do fluxo. A redução desta grandeza com o aumento da quantidade de polímero na fórmula está coerente com as alterações das fórmulas, pois tal componente foi substituído por pó de ferro que apresenta maior densidade aparente. Considerando que a variação da área correspondente ao fluxo na seção transversal dos arames foi mínima e se manteve dentro do intervalo de confiança pode-se concluir que houve preservação do volume de fluxo no interior do arame, ou seja, o preenchimento foi completo.

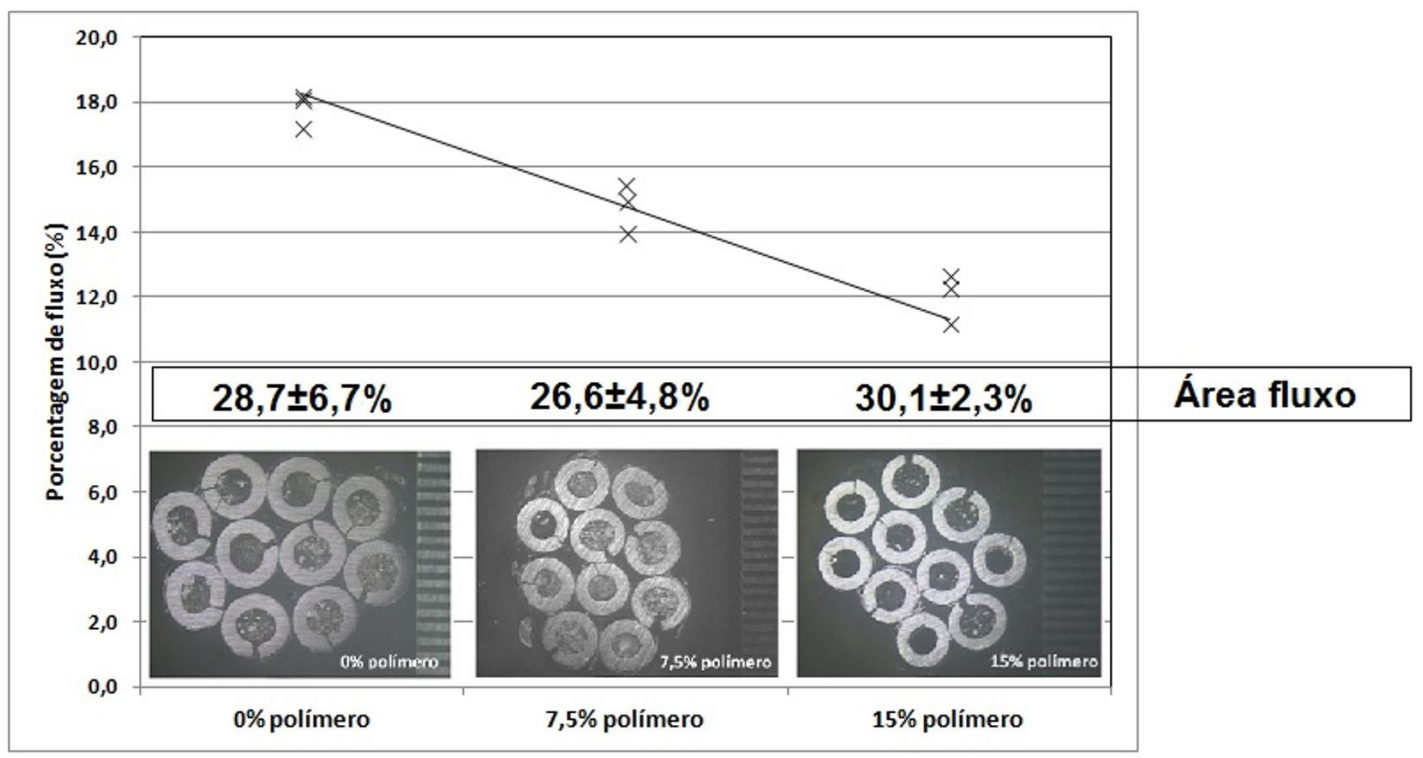

Figura 7. Porcentagem e área de fluxo nos arames tubulares (Intervalo de confiança 95\%).

Tais observações demonstram, em síntese, que a técnica de fabricação utilizada foi capaz de produzir arames celulósicos com adição de polímero de acordo com os critérios e especificações normalmente exigidos pelos fabricantes ou AWS para consumíveis classificados.

\subsection{Análise química do metal de solda}

Na Figura 8 são apresentados os teores de carbono, silício e manganês das soldas depositadas pelos arames. Analisando os resultados obtidos verifica-se que há uma redução no teor dos elementos analisados com o aumento na quantidade de polímero presente na formulação. A variação entre os metais de solda produzidos pelos arames com 0 e 7,5\% de polímero não foi significativa. Comparando estes teores com os típicos do metal de solda depositado pelo eletrodo revestido celulósico que teve sua fórmula empregada como base para a produção dos arames (AWS E6011), verifica-se que não há diferenças consideráveis quanto aos valores de silício e manganês (típicos de 0,20\% e 0,50\% respectivamente). Já o teor de carbono encontra-se, para estes consumíveis, acima do típico que é inferior a 0,1\%. 


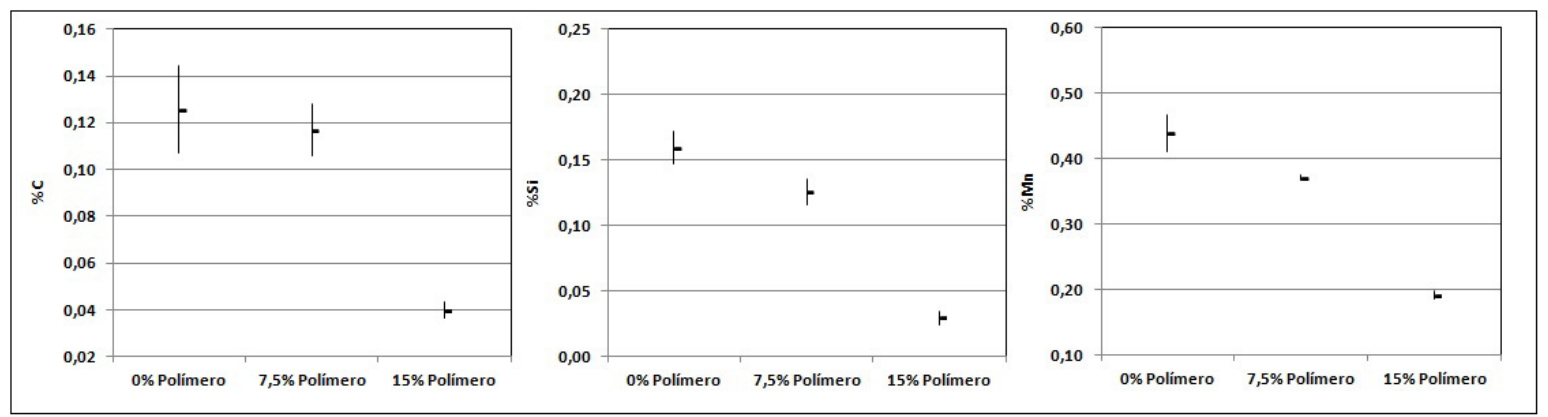

Figura 8. Teores de carbono, silício e manganês do metal de solda sem diluição (Intervalo de confiança 95\%).

O metal de solda produzido pelo arame com 15\% de polímero, por sua vez, apresentou teores consideravelmente baixos dos elementos analisados em comparação aos outros consumíveis. A priori, imaginava-se que o aumento na quantidade de polímero promovesse tanto aumento nos teores de silício e manganês quanto de carbono do metal de solda devido a maior disponibilidade deste a partir do emprego de mais polímero. Este comportamento é explicado pela reação preferencial do carbono com o oxigênio a determinadas temperaturas impedindo sua combinação com silício e manganês que permanecem no metal de solda. Todavia, os ensaios exploratórios realizados neste estudo não permitem identificar a causa de tal discrepência no comportamento dos consumíveis, em especial no que contém $15 \%$ de polímero. Como a explicação deste fenômeno envolve o estudo das reações competitivas entre os elementos dos componentes do fluxo incorporados ao metal de solda líquido e atmosfera que envolve o arco é necessário, para aprofundar a discussão, realizar estudos e análises complementares. A análise do teor de oxigênio no metal de solda e dos gases resultantes do processo de soldagem pode ser uma alternativa para explicar os resultados obtidos. Além dos aspectos termodinâmicos discutidos não se pode desconsiderar também as alterações que o componente adicionado promove no comportamento do arco pela incorporação do íon fluor.

Um dos objetivos imaginados, a partir da adição de polímero ao fluxo dos arames tubulares, seria controlar o teor de hidrogênio difusível do metal de solda conforme relatado por Vaz et al. [10] no caso de eletrodos revestidos básicos com adição deste. Nas condições avaliadas neste estudo, os resultados indicaram que não houve redução no teor de hidrogênio difusível nos arames tubulares com maiores quantidades deste componente. Boniszewski [7] relata que o metal de solda produzido por eletrodos revestidos celulósicos apresenta teores de hidrogênio difusível superior a $30 \mathrm{ml} / 100 \mathrm{~g}$ de metal de solda podendo chegar até $50 \mathrm{ml} / 100 \mathrm{~g}$ de metal de solda. Ao comparar os resultados obtidos (Figura 9) com o relatado verifica-se que os consumíveis produzidos apresentaram teores médios inferiores ou próximos ao mínimo comentado pelo pesquisador. O consumível produzido sem a adição de polímero apresentou o menor valor médio. Este fato é justificado pela ocorrência de uma medida bem inferior ao típico para consumíveis celulósicos e diferentes das demais. Os valores médios e intervalos de confiança calculados desprezando este valor apresentados na figura estão coerentes com a hipótese apresentada e reforçam que não há tendência de redução no teor de hidrogênio difusível com o emprego do polímero. Uma das hipóteses para justificar a ineficácia do polímero empregado na redução do hidrogênio difusível do metal de solda é a quantidade excessiva de hidrogênio presente na formulação (principalmente através da celulose). Nesta condição, o aporte de polímero pode ter sido insuficiente para promover a redução esperada. Como alternativa, pode ser proposta a produção de arames tubulares com redução gradativa da quantidade de celulose na formulação.

\subsection{Avaliação dos cordões de solda depositados}

Os cordões de solda depositados pelos arames tubulares sobre chapa são apresentados na Figura 10. A avaliação visual destes indica a presença de quantidade considerável de respingos aderidos à superfície da chapa. Tal característica está coerente com o comportamento esperado para consumíveis contendo celulose.

Na Figura 11 são mostrados exemplos de macrografias da seção transversal dos cordões de solda produzidos e as medições de largura, penetração e reforço realizadas em função da quantidade de polímero. Observando as macrografias nota-se que, mesmo não tendo sido empregado gás de proteção externo na soldagem com os arames tubulares, os cordões não apresentaram porosidade. Este é um excelente resultado considerando o fato dos consumíveis serem experimentais. Quanto a morfologia dos cordões de solda observa-se que o houve 


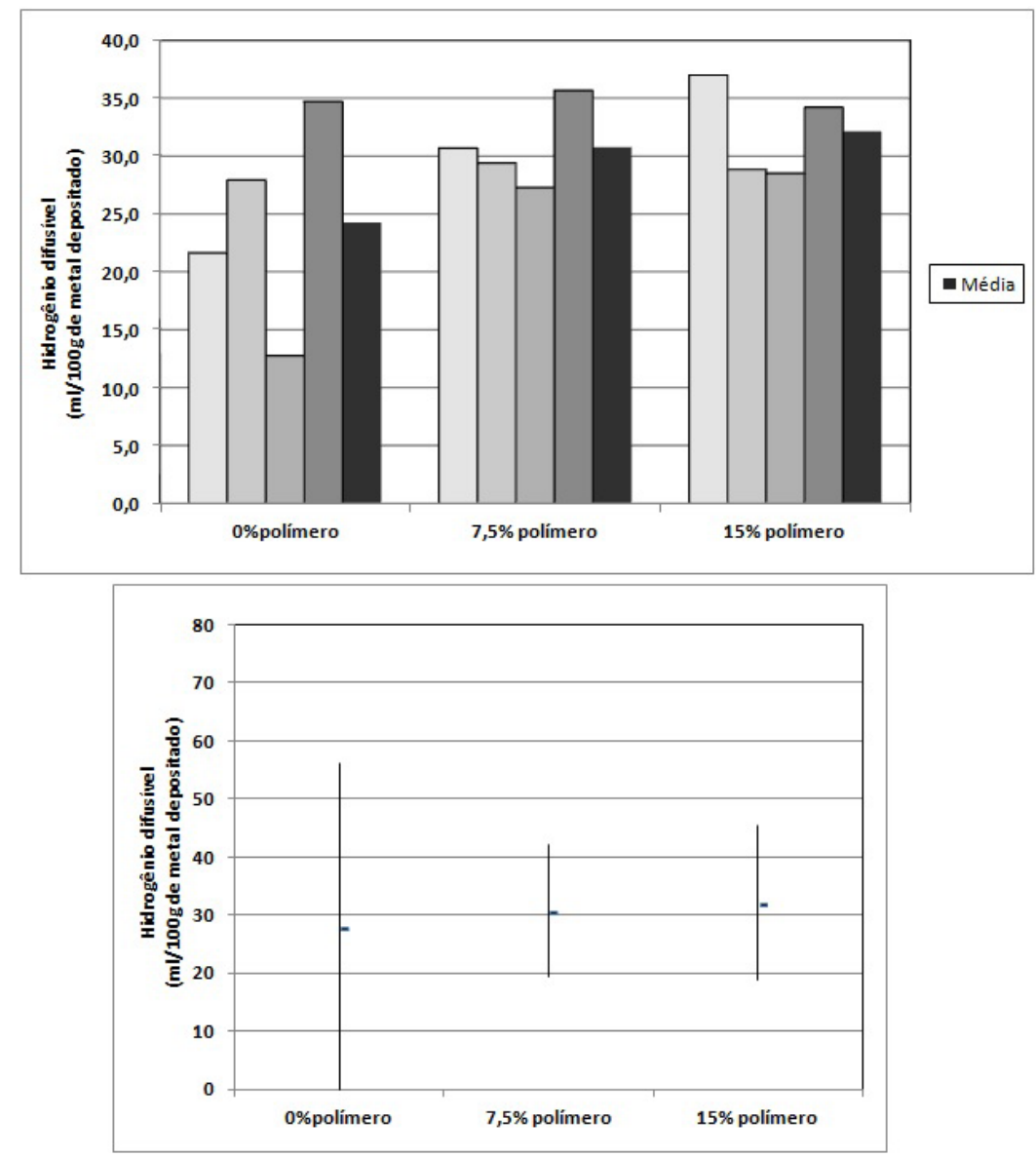

Figura 9. Teor de hidrogênio difusível do metal de solda depositado pelos arames tubulares. Valores individuais, médias e intervalo de confiança (95\%).
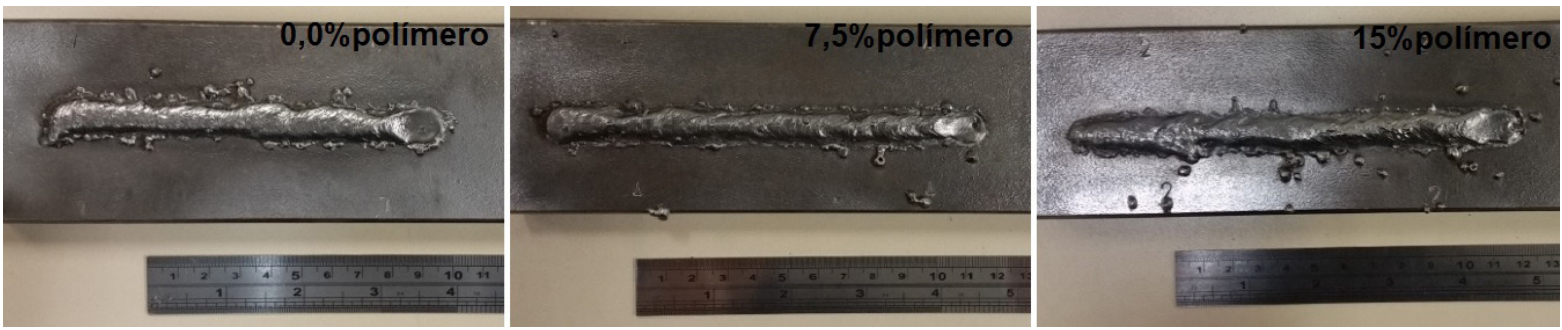

Figura 10. Cordões de solda produzidos com os arames tubulares.

uma tendência ao aumento na penetração em função do aumento na quantidade de polímero utilizado. Este comportamento está coerente com o observado para eletrodos revestidos com adição de diferentes quantidades de polímero [11]. É importante observar, todavia, que este acréscimo se encontra dentro do intervalo de confiança. As medições também indicaram redução no reforço e aumento na largura dos cordões com aumento do teor de polímero dentro dos limites dos intervalos de confiança. A redução no reforço pode ser explicada pela redução no teor de pó de ferro com o aumento da quantidade de polímero. Isto ocorre porque foi mantida constante a velocidade de soldagem em todos os testes. A variação destes parâmetros resultou em aumento na diluição dos cordões de solda com aumento do polímero em condições semelhantes às obervadas para as demais grandezas medidas, ou seja, dentro do intervalo de confiança. 


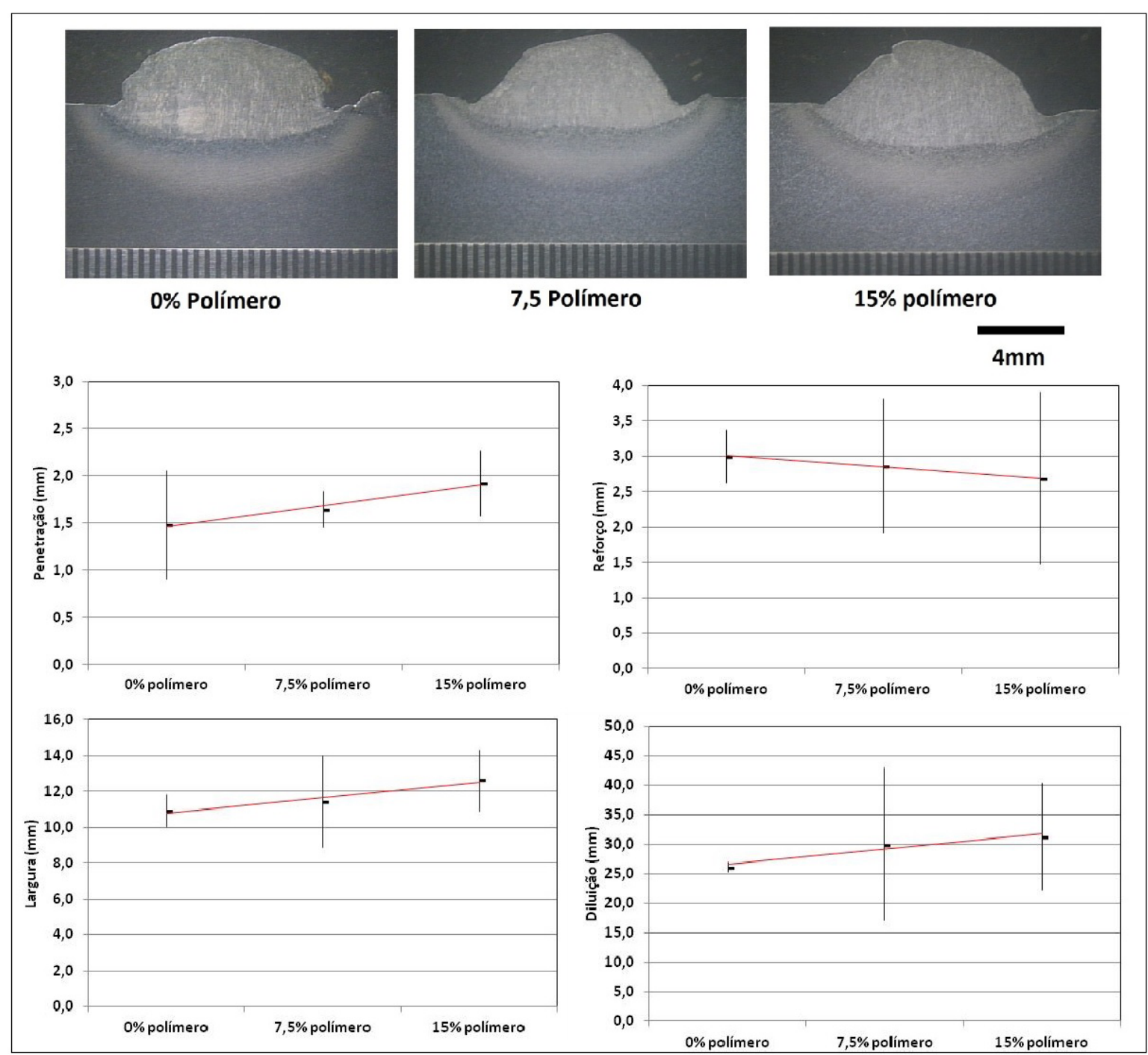

Figura 11. Macros, dimensões e diluição dos cordões de solda depositados com os arames (Intervalo de confiança 95\%).

\subsection{Análise dos sinais elétricos}

Oscilogramas de corrente e tensão típicos obtidos durante a soldagem com os três tipos de arames tubulares investigados neste estudo são apresentados na Figura 12. De modo geral, analisando o comportamento observado, nota-se a ocorrência de curtos circuitos e morfologia indicativa deste modo de transferência metálica. Nota-se, também, a ocorrência de eventos com tensões em vazio variando em função da quantidade de polímero no arame. Tal fenômeno é ilustrado nos oscilogramas da Figura 13 considerando menores intervalos de tempo (1 segundo) onde as tensões em vazio são sinalizadas pelos círculos em preto e curtos-circuitos rápidos pelos círculos em azul. No gráfico gerado com os dados coletados durante a soldagem utilizando o arame com 15\% de polímero (c) não foram observadas tensões em vazio no intervalo de tempo considerado.

Para verificar possíveis alterações na frequência de ocorrência destes fenômenos foram obtidos histogramas de tensão para cada formulação analisada, como apresentado na Figura 14. A princípio, é possível observar que o comportamento das tensões não alterou significativamente com a variação da formulação, apresentando curvas parecidas. Entretanto, nota-se uma pequena exceção na região de 0-10 V que é a região característica de ocorrência 


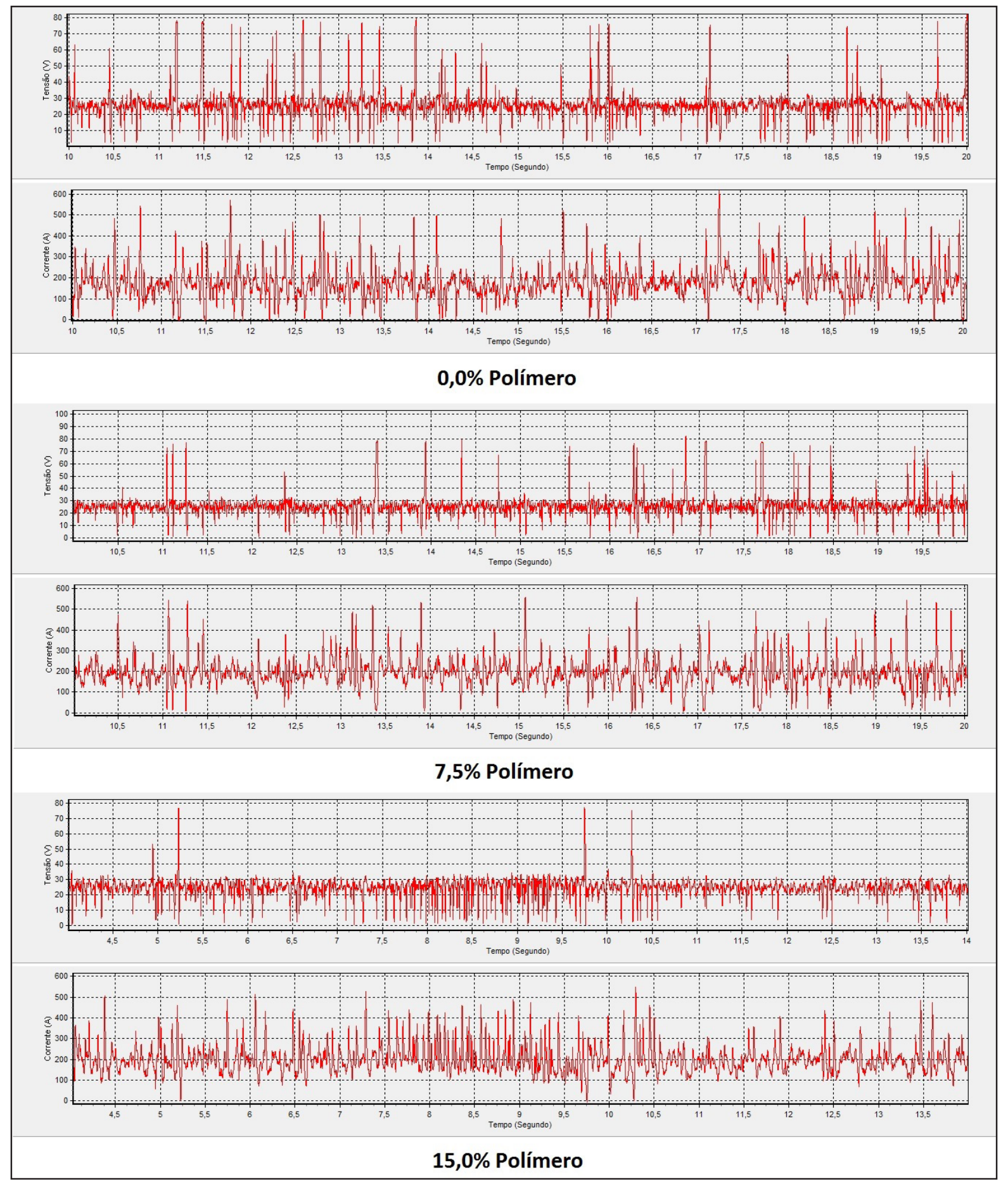

Figura 12. Oscilogramas de tensão de corrente obtidos durante a soldagem com os arames.

de curtos-circuitos, onde se pode observar uma maior ocorrência de curtos-circuitos para a fórmula com 0,0\% polímero. A região entre 70 e $80 \mathrm{~V}$, correspondente a tensão em vazio, foi ampliada para verificar se houve variação na ocorrência de extinções do arco. Com o aumento da porcentagem de polímero na composição do fluxo, nota-se uma redução da ocorrência de deste fenômeno. As curvas dos arames com $0 \%$ e 7,5\% de polímero na formulação apresentam regiões bem próximas, mas é evidente a diminuição de ocorrências indesejáveis nesta última. Já na curva produzida durante a soldagem com o arame contendo $15 \%$ de polímero na formulação é notória tal diminuição 
Arames Tubulares Celulósicos: Influência da Adição de Polímeros sobre a Estabilidade do Processo e Propriedades do Metal de Solda Produzido

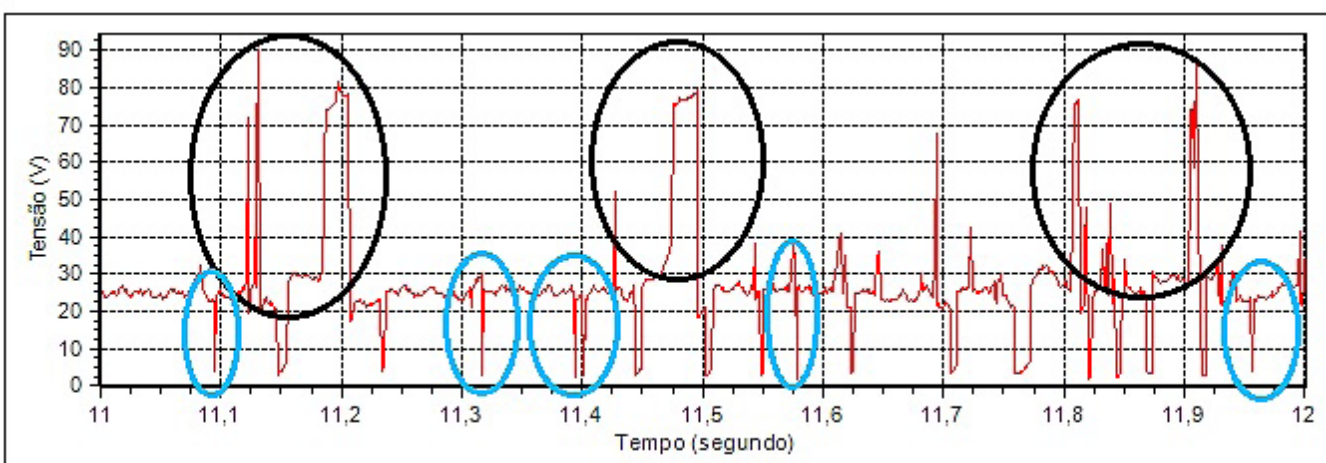

(a)

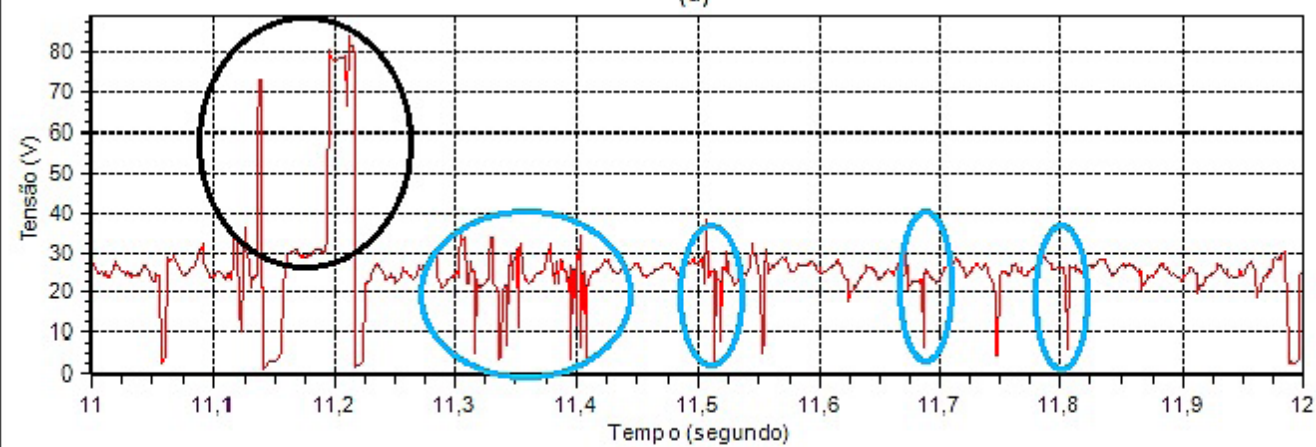

(b)

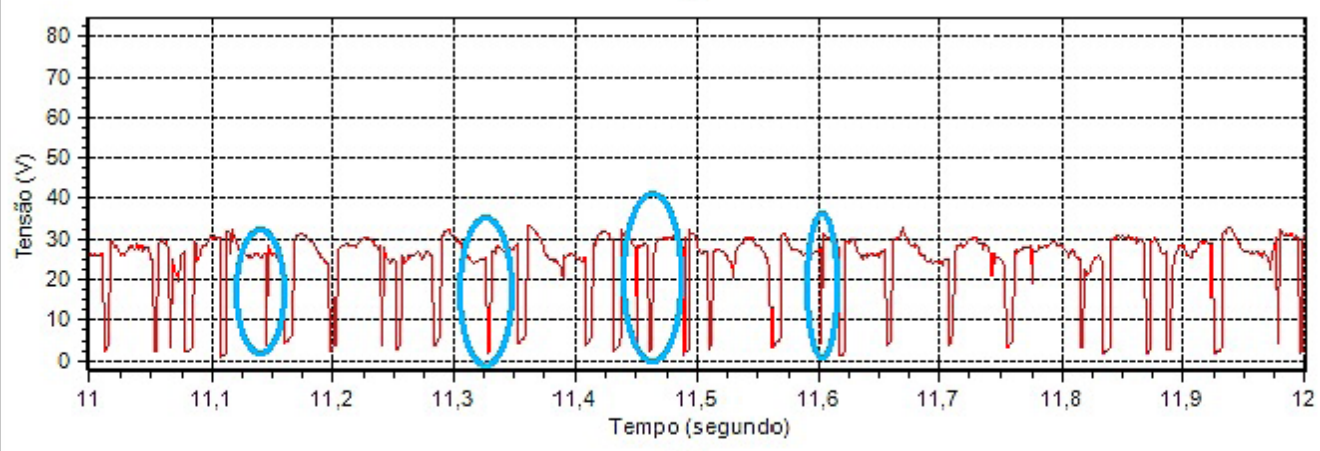

(c)

Figura 13. Oscilogramas de tensão para cada formulação. (a) 0,0\% Polímero, (b) 7,5\% Polímero, (c) 15\% Polímero.

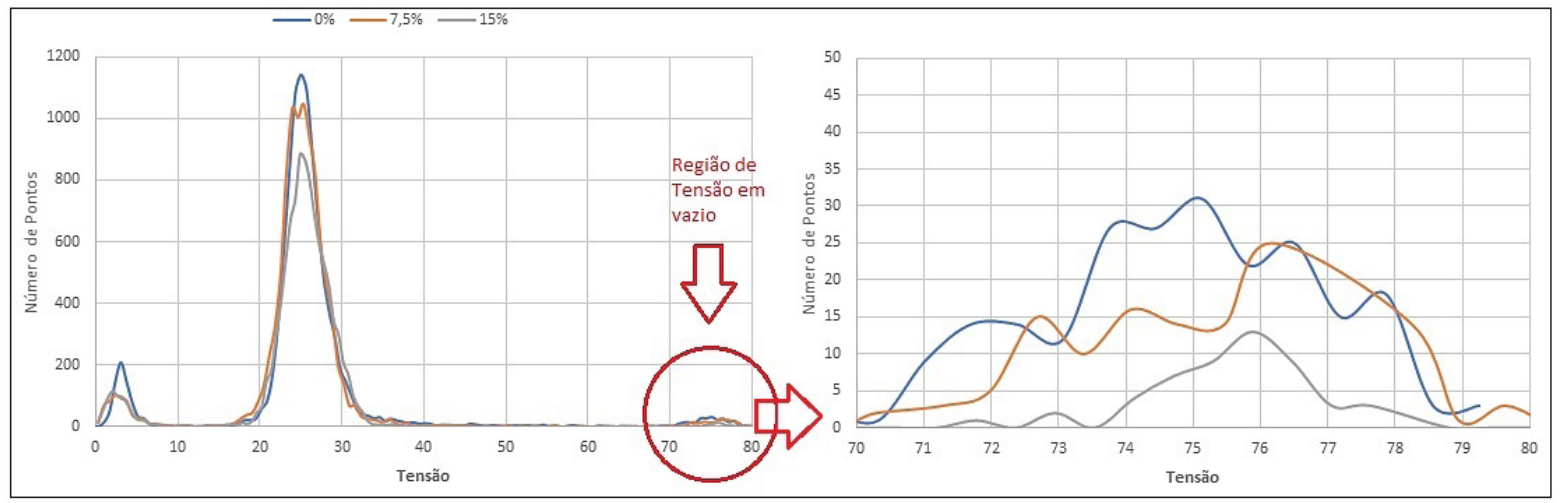

Figura 14. Histograma de tensão dos diferentes arames tubulares investigados e ampliação da região de ocorrência de tensão em vazio (direita). 
em relação às curvas de $0 \%$ e 7,5\%. Tal redução, com o aumento da quantidade de polímero, pode estar associada a diversos fatores que não podem ser identificados a partir dos ensaios realizados durante este trabalho.

A tensão média $\left(V_{m}\right)$ e desvio padrão da tensão média $\left(\sigma V_{m}\right)$, corrente média $\left(I_{m}\right)$ e desvio padrão da corrente média $\left(\sigma \mathrm{I}_{m}\right)$ são representados na Figura 15 . Nestes gráficos nota-se uma tendência de diminuição na tensão média e aumento na corrente média que podem ser justificadas, entre outros fatores, pela diminuição na ocorrência de tensões em vazio.
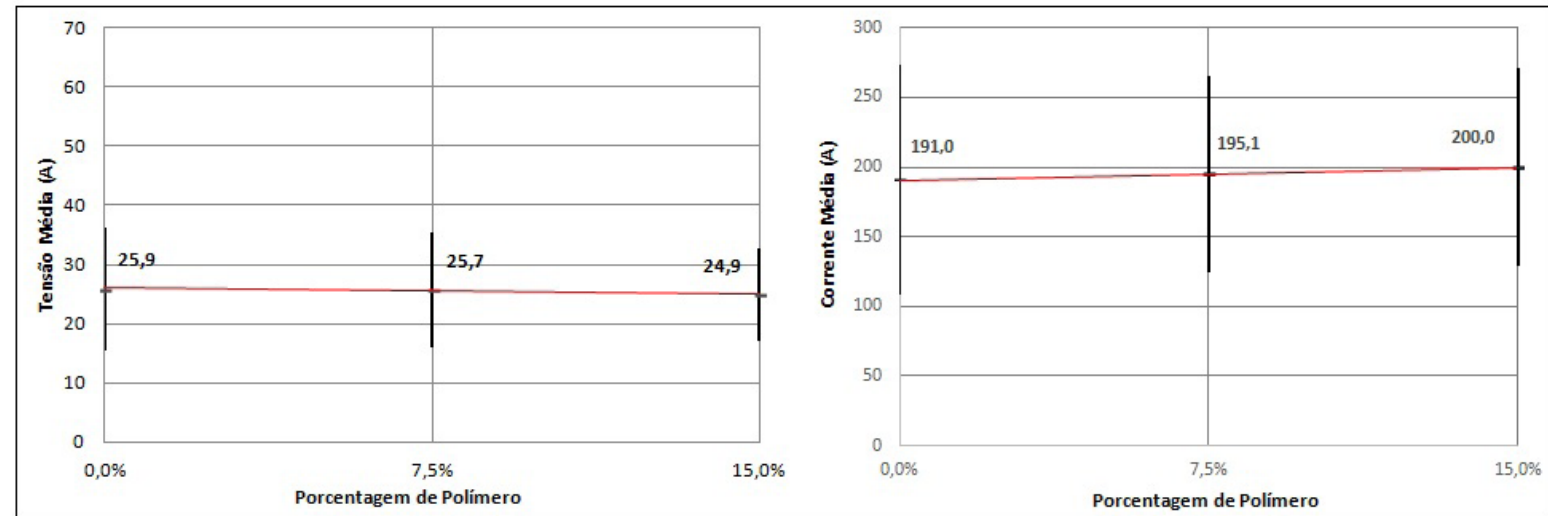

Figura 15. Tensão e corrente média $\left(V_{m}\right.$ e $\left.I_{m}\right)$ e desvio padrão da tensão e corrente média $\left(\sigma V_{m}\right.$ e $\left.\sigma I_{m}\right)$.

Curtos-circuitos rápidos é outro importante fator na avaliação da estabilidade da transferência metálica, pois pode causar variações anormais de tensão que resultam em uma forte perturbação no arco elétrico e produção de respingos [13]. Neste trabalho foram considerados curtos-circuitos rápidos aqueles com duração igual ou menor que 2 milissegundos. $O$ software Sinal foi utilizado na determinação da quantidade destes no intervalo de 10 segundos para cada fórmula para, posteriormente, calcular a frequência de curtos-circuitos rápidos através da razão entre o número de curtos-circuitos rápidos e o intervalo de tempo. Na Figura 16 é apresentada esta frequência para as três fórmulas de arame tubular investigadas. Não foi observada nenhuma mudança significativa na frequência de curtos-circuitos rápidos entre os arames contendo $0,0 \%$ e $7,5 \%$ de polímero. No arame com $15 \%$ de polímero, contudo, houve uma diminuição em torno de $25 \%$ na frequência de ocorrência deste fenômeno em relação às outras formulações.

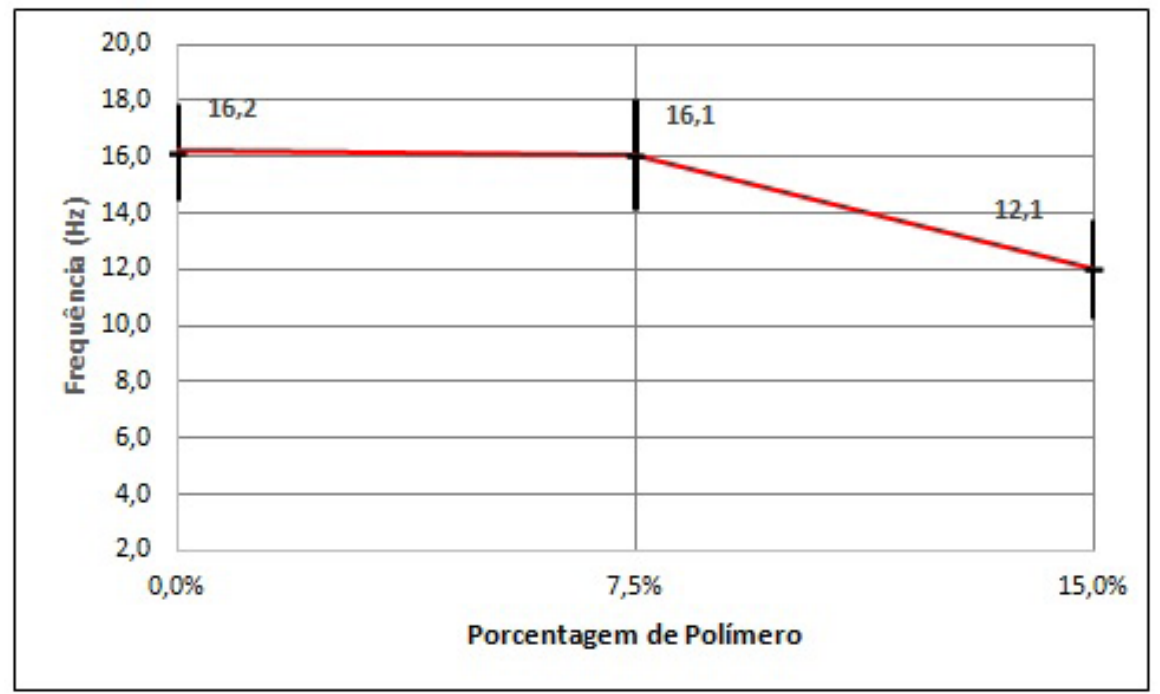

Figura 16. Gráfico da frequência de curtos-circuitos rápidos para cada formulação analisada. 
O coeficiente de variação (CV) é um índice estatístico adimensional que permite a análise de flutuações em sinais. Fenômenos indesejáveis durante o processo de soldagem, como extinção do arco e curtos-circuitos rápidos, podem causar variações do comprimento do arco no instante exatamente antes do início ou do exatamente após o fim desses fenômenos, causando variações da tensão do arco elétrico. Essas variações podem ser avaliadas através deste índice. Assim, pode-se afirmar que menores desvios de tensão média, consequentemente, menores valores de CV, teoricamente resultam em um cordão de solda com menores defeitos e um processo mais estável. Para a comparação do comportamento do arco, entretanto, é necessário uso de filtros de passa-baixa, que também podem ser usados através do software Sinal, para remoção de picos de curto-circuitos, ou picos de tensão em vazio e para obter apenas oscilogramas de tensão com o arco em operação [14]. Os resultados apresentados anteriormente apontam que para o arame tubular com formulação de $15 \%$ de polímero houve redução no número de ocorrências de tensão em vazio durante o processo de soldagem e também na ocorrência de curtos circuitos rápidos, indicando assim, que este consumível que apresenta maior estabilidade durante a soldagem. Este resultado é reforçado pelo coeficiente de variação (CV) calculado para os três arames estudados apresentado no gráfico da Figura 17 onde nota-se redução deste a medida que se aumenta a quantidade de polímero presente na fórmula do consumível.

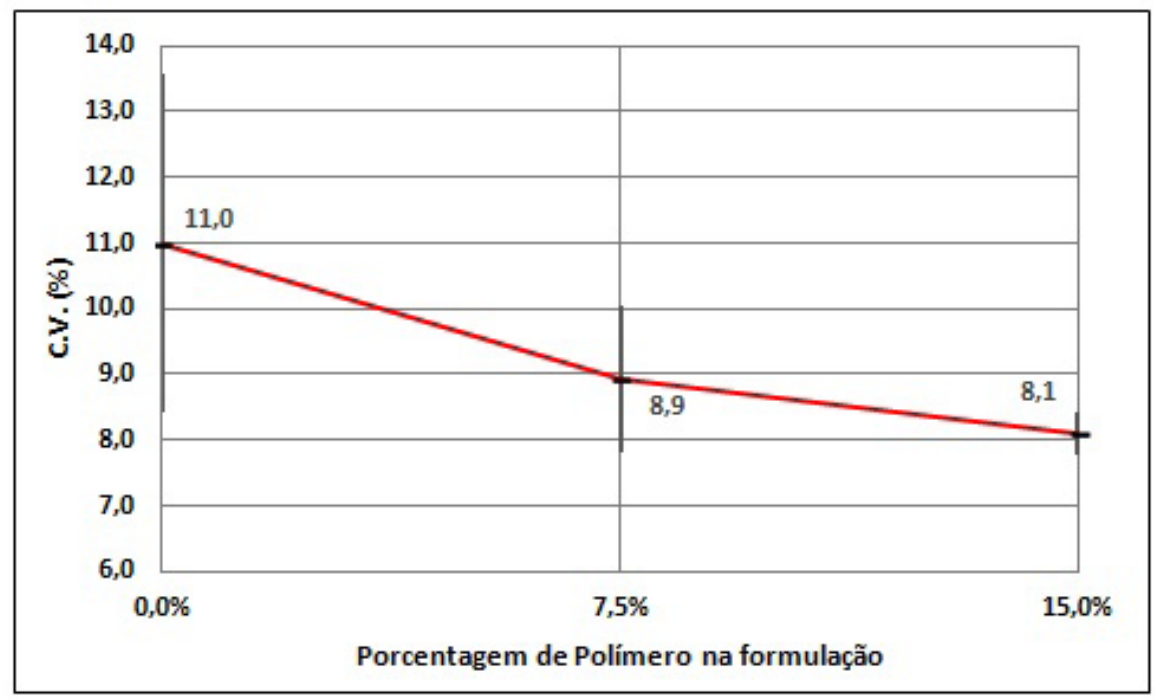

Figura 17. Coeficiente de Variação (CV) para cada formulação utilizada.

\section{Conclusões}

Os resultados obtidos nos experimentos realizados nesse estudo permitem concluir que:

- O diâmetro dos arames tubulares produzidos variou de maneira aleatória dentro dos limites de especificação para esta classe de consumíveis;

- O percentual de fluxo em peso reduziu com o aumento no teor de polímero da formulação. Tal resultado é justificado pela substituição de pó de ferro com maior densidade por polímero; A mínima variação no percentual de fluxo medido em cada um dos arames não indicou problemas de alimentação ou de heterogeneidade do fluxo;

- As medidas do percentual de área do fluxo realizadas nas macrografias não variaram em função do arame demonstrando que houve preenchimento total do arame pelo fluxo;

- O comportamento constante durante a soldagem com os arames tubulares reforça, em conjunto com os outros resultados obtidos, a homogeneidade destes; 
- Os metais de solda depositados pelos arames tubulares com 0 e 7,5\% de polímero apresentaram composição química típica de metais de solda produzidos com eletrodos revestidos celulósico com a mesma base de fórmula; Para o arame com 15\% de polímero houve uma redução considerável nos teores de Si e Mn;

- O teor de hidrogênio difusível do metal de solda não apresentou redução com o aumento no teor de polímero como se esperava. Os teores obtidos se encontram próximos ao mínimo típico para eletrodos revestidos do tipo celulósico;

- A análise das macrografias não indicou a presença de porosidade nos cordões de solda produzidos e as medidas de penetração, largura, reforço e diluição realizadas apresentam tendências de variação que se encontram dentro dos intervalos de confiança. A adição de polímero resultou em uma tendência no aumento da penetração conforme já observado para outros consumíveis com adição deste componente;

- Com o aumento da porcentagem de polímero houve uma diminuição da quantidade de ocorrências de tensão em vazio durante a soldagem;

- Ocorreu uma redução significativa em torno de $25 \%$ de curtos-circuitos rápidos no arame com $15 \%$ de polímero em relação aos arames de $0 \%$ e 7,5\%, enquanto nestes dois últimos não houve variação significativa;

- Observou-se uma diminuição do CV com o aumento da porcentagem de polímero no arame, confirmando a tendência de maior estabilidade com o aumento na quantidade de polímero utilizada observada através dos demais parâmetros investigados.

\section{Agradecimentos}

Os autores desse trabalho agradecem ao LRSS - Laboratório de Soldagem Robótica e Simulação da Universidade Federal de Minas Gerais pela estrutura necessária à realização das soldagens e ensaios desse estudo.

\section{Referências}

[1] Widgery D. Tubular wire welding. 1st ed. Cambridge: Woodhead Publishing Ltd; 1994. $145 \mathrm{p}$.

[2] Surian ES. Consumibles para soldadura por arco eléctrico: algunos desarrollos recientes. Soldagem e Inspeção. 2013;18(1):77-89. http://dx.doi.org/10.1590/S0104-92242013000100011.

[3] Oliveira BV. Desenvolvimento, construção e montagem de equipamento para fabricação do arame tubular para soldagem [trabalho de graduação]. Belo Horizonte: Univesidade Federal de Minas Gerais; 2010.

[4] Mendes NS, Bracarense NAQ, Perez MR, Gonzáles LP. Máquina piloto para fabricação de arame tubular. In: XXXVIII Consolda; 2012 Outubro 15-18; Ouro Preto. São Paulo: ABS; 2012.

[5] Bracarense AQ, Borba DHS. Desenvolvimento do arame tubular celulósico para soldas de passe de raiz e alta penetração. In: XXXIX Consolda; 2013 Novembro 25-28; Curitiba. São Paulo: ABS; 2013.

[6] Bracarense AQ. Arame tubular celulósico para soldagem [BR1020140085459]. 2014 [acesso em 29 nov. 2017]. Disponível em: http://somos.ufmg.br/unidade/escola-de-engenharia

[7] Bonizewski T. Manual metal arc welding - old process, new developments. Part II: Understanding MMA electrodes. The Metallurgist and Materials Technologist. 1979;11(11):640-643.

[8] Vaz CT, Bracarense AQ. The effect of the use of PTFE as a covered-electrode binder on metal transfer. Soldagem \&
Inspeção. 2015;20(2):160-170. http://dx.doi.org/10.1590/01049224/SI2002.04.

[9] Vaz CT, Bracarense AQ, Felizardo I, Pessoa ECP. Impermeable low hydrogen covered electrodes: weld metal, slag, and fumes evaluation. Journal of Materials Research and Technology. 2012;1(2):64-70. http://dx.doi.org/10.1016/ S2238-7854(12)70012-1.

[10] Vaz CT, Bracarense AQ. Influência do uso de PTFE como aglomerante em eletrodos revestidos básicos sobre a formação de ferrita acicular no metal de solda. Soldagem \& Inspeção. 2015; 20(2): 160-170.

[11] American Welding Society. AWS A5.20-95: specification for carbon steel electrodes for flux cored arc welding. Miami: AWS; 1995.

[12] American Welding Society. AWS A4.3-93: standard methods for determination of diffusible hydrogen content of martensitic, bainitic and ferritic steel weld metal produced by arc welding. Miami: AWS; 1993.

[13] Modenesi PJ. Introdução à física do arco elétrico e sua aplicação na soldagem dos metais. Belo Horizonte; 2015.

[14] Leonello A Fo. Análise da influência dos parâmetros do processo de soldagem com eletrodos revestidos na estabilidade do arco e características geométricas do cordão-Brasil [dissertação de mestrado]. Itajubá: Universidade Federal de Itajubá; 2005. 44 p. 